\title{
A REVIEW ON LACTIC ACID BACTERIA FROM AGRICULTURAL
} SOIL

\author{
BHATT $D^{1}$, UPADHAYAY $D^{2}$, ANDHARE $P^{2}$ AND PRAJAPATI $P^{2 *}$ \\ 1: PG Student M.Sc. (Microbiology), Department of Microbiology, Parul Institute of Applied \\ Science, Parul University, Po-Limda 391760, Ta-Waghodia, Dis- Vadodara. \\ 2: Assistant Professor, Department of Microbiology, Parul Institute of Applied Science, Parul \\ University, Po-Limda 391760, Ta-Waghodia, Dis- Vadodara \\ *Corresponding Author: Dr. Priyanka Prajapati; E Mail: priyanka.mistry82141@paruluniversity.ac.in; Tel: \\ $+919913562946$ \\ Received 22 ${ }^{\text {nd }}$ Jan. 2021; Revised $25^{\text {th }}$ Feb. 2021; Accepted $26^{\text {th }}$ March 2021; Available online $1^{\text {st }}$ April 2021 \\ https://doi.org/10.31032/IJBPAS/2021/10.4.1046
}

\begin{abstract}
The Lactic acid bacteria is very well-known Bacteria, Lactobacillus are an order of Grampositive, low-GC, acid- Tolerant, generally nonsporulating, non-respiring, it is either rod-shaped (bacilli) or (cocci) bacteria that share common metabolic and physiological characteristics.LAB has a long history of being used safely in a variety of food products. Members of the genera Lactococcus, Lactobacillus, and Bifidobacterium have been designated as "generally recognized as safe.Members of the genera Lactobacillus and Bifidobacterium spp.are the most commonly studied intestinal bacteria for potential probiotic use.Lactic acid bacillus are bacteria that have been inactivated and are beneficial to the stomach. They stop other pathogenic bacteria from growing and causing diarrhea or other bacterial infections. It aids in the treatment of bacterial infections. (LAB) are heterogenous group of bacteria which plays a significant role in a variety of fermentation processes. They ferment food carbohydrates and produce lactic acid as the main product of fermentation like cheese, yoghurt, fermented milks), meat, fish, fruit, vegetable and cereal products. Current studies suggest that lactic acid bacteria possess anti-obesity and antidiabetic propensities on their hosts and thus can play a crucial role in human health care.
\end{abstract}


Research in the rheological and physicochemical properties of ice cream as well as its applications are also on the increase.

Keywords: Lactic acid bacteria, agricultural soil, nutrient agar, MRS agar

\section{INTRODUCTION}

The Lactic acid bacteria are very well-known Bacteria, Lactobacillus it is either rod-shaped (bacilli) or (cocci) bacteria that share common metabolic and physiological characteristics. These bacteria, usually found in decomposing plants and dairy products such as milk and cheese etc. common name is given also known as (LAB). In laboratory usually media used for LAB include a carbohydrate source. Mainly microorganisms are used in food industry. Aerococcus, Carnobacterium, Enterococcus, Lactobacillus, Lactococcus, Leuconostoc, Oenococcus, Pediococcus, Streptococcus, Tetragenococcus, Vagococcus, Weissella. This are Lactic acid bacteria genera [1]. Lactic acid bacteria are one of the most significant groups of probiotics. Organisms, mainly used in fermentation and waste. Main role of lactic acid bacteria is that microorganisms can enhance lactose digestion and stimulates the immune system. Lactic acid bacteria are commonly found in any environment rich in carbohydrates such in plants and fermented foods and agricultural waste.Also help in production of bioenergy and biogas. The first pure culture of LAB was obtained in 1873.
However, milk souring and lactic acid producing bacteria considered as same, LAB find wide application in food industry and medicine,Lactic acid is main contain of LAB synthesis primarily consumed by food industry. LAB is also source of low calories sugars, ethanol, and EPS. LAB has a wide range of applications in the food and medical industries, but it can also be used in other fields such as waste depletion and bioremediation. This material can be contained in waste, waste substrate containing this substance, and food residue in this LAB. Carbohydrate can be extracted from waste, such as chitin. Lactic acid is the most common component of LAB synthesis, and it is mainly used by the food industry. LAB is the same way [1]. Biofuel, vitamins, antibiotics, and a number of other products are made from agro-industrial wastes using solid state fermentation. In this agriculture, waste includes orange peels, fermented rice, crops, fruit waste, and waste grass, among other things. Lactic acid was produced in 2009 via a fermentation process [2].

Bui Hoang Dang Long, isolated the LAB strain from various waste or soil samples. He 
collected 66 samples of agricultural soil, isolated them, and determined various morphological properties of the samples, such as coccus, bacillus, and fungi [3].

\section{LACTIC ACID BACTERIA AS} BIOCONTROL AGENT

Lactic acid bacteria as biocontrol agent of soil-borne pathogen. From various authors it is said that Microorganisms' function as in food production and preservation.Food fermentations a total of 294 LAB isolates were collected and isolated [4]. Lactic acid bacteria (LAB) may be a promising new bacterial community for biological control of soil-borne pathogens. 294 isolates of LAB were collected from soil and the rhizosphere of maize, rye, carrots, garden soils, and compost from two sources and tested in a confrontation assay against Pythium ultimum. In food science, lactic acid bacteria (LAB) have a long and significant history. The LAB contains a wide range of cell types as well as physiological and biochemical properties. Various isolations of LAB from milk, fermented foods, and plants have been frequently published in previous studies. Studies on soil isolation, on the other hand, are rare, despite the fact that it is well established in soil, When the isolates were examined, only Gram-positive bacteria were detected [5]. Lactic acid bacteria (LAB) have been shown to be capable of killing certain fungi. $\mathrm{LAB}$ is commonly derived from fermented animal and vegetable matter. A low rate of LAB "somnicells" can be found in a number of environments that are close to these biodatas, such as the floor of a henhouse, the rhizosphere of fruit, and the field around a horse barn. LAB isolation from soil and water is still difficult to come by, but their presence in rhizospheres' samples has been confirmed [6, 7]. But their existence in rhizospheres' samples has been reported. They isolated and characterized $\mathrm{LAB}$ for the first time from olive tree rhizosphere samples and desert truffle rhizosphere samples. The findings showed that the isolates had a high degree of antimicrobial activitysuggesting that the rhizosphere may be a common source for identifying LAB with substantial technological potential for biocontrol of food-, plant-, and animal-borne pathogens. [8-10].

CHARACTERIZATION OF LACTIC ACID BACTERIA AND AGRICULTURAL SOIL

Lactic Acid Bacteria from a Wild Boar's Gastrointestinal Tract as Potential Probiotics were studied. Lactic acid bacteria (LAB) are useful probiotic microorganisms that are also important members of the human and mammalian gut microbiota, supporting the 
host's wellbeing.LAB has a long history of being used safely in a variety of food products. As a result, members of the genera Lactococcus, Lactobacillus, and Bifidobacterium have been designated as "generally recognized as safe." As a result, members of the genera Lactobacillus and Bifidobacterium spp. are the most commonly studied intestinal bacteria for potential probiotic use [11]. There has been no research done to measure the positive effects of microbial diversity, soil and plant quality, and ecosystem sustainability. Soil microbial dynamics play a big role in ecosystem functioning. There have been reports of differences in microbial properties and activities in soils, but they are limited to general ecological enumeration methods or activity levels.which have a limited capacity to characterize a specificecosystem microbial community and their responses to stress have historically been studied at the process level, in terms of total numbers of microorganisms, biomass, respiration rates, and enzyme activities, with little focus on responses at the group or organismal levels $[\mathbf{1 1}, \mathbf{1 2}]$.

SOME CURRENT CHALLENGES IN LAB APPLICATION AS PROBIOTIC

Certain problems have hampered the use of probiotic LABs, some of which will be discussed in this review. Despite the fact that probiotics have many health benefits, these arguments can only be made if a large number of viable cells enter the small intestine. After being exposed to low $\mathrm{pH}$ after fermentation, many probiotic bacteria have been found to die in food products [13]. Detailed studies of the physiology of LABs regarding they interact with other microbes and as they interact with foods are still lacking.These include a series of mathematical models and technologies investigating LAB bioinformatics, which can be used to reasonably predict responses of LABs in certain food systems as well as explore further applications. Although genetic engineering of LABs can have some positive effects on the food and pharmaceutical industries, legal concerns regarding the technology's use, which is still controversial in some quarters, could restrict its use [14].

\section{LACTIC ACID PRODUCING \\ MICROORGANISMS IN SOILS}

Bacteria are one of the most abundant groups of microorganisms found in soil with most of them present around the rhizospheric region. Bacteria in the rhizosphere are larger and have higher proportions of Gramnegative and denitrifying bacteria than those in the bulk soil. LAB found in agricultural soil. Bacterial biomass in soil varies between 300 and $3000 \mathrm{~kg} / \mathrm{ha}$. A gramme of soil 
contains approximately 108 to 109 bacteria, the majority of which ( $>99$ percent) have not been or cannot be cultured in the laboratory. Bacillus, Arthrobacter, Pseudomonas, Agrobacterium, Alcaligenes, Clostridium, Flavobacterium, Corynebacterium, Micrococcus, Xanthomonas, and Mycoba are some of the most common bacterial genera isolated from soil $[\mathbf{1 5}, \mathbf{1 6}]$.

According to Texas A \& M University, an average gramme of soil contains between 100 million and one billion bacteria. A single acre of soil can contain up to 3,000 pounds of microbes, or around 12 pounds per square foot. These microscopic creatures come in a number of shapes andsizes, and they play an important role in the soil ecosystem. According to the New South Wales Department of Primary Industries, bacteria species such as Bacillus subtilis and Pseudomonas fluorescens work as decomposers, digesting organic materials and breaking them down into soil and compost. Bacteria are important for removing nitrogen gas from the air and converting it to a mineral from plants can use. Aerobic bacteria, which need oxygen to survive, thrive in well-drained soils with little standing water. These bacteria make up the majority of bacteria in most soils and are also needed for nitrification. Ammonium is converted to nitrates by these bacteria. [15, 16].

\section{CONCLUSION}

Lactic acid bacteria are listed in this review paper as contributing to the tremendous environmental and health benefits. Fresh vegetables constitute a good source of lactic acid bacteria with ability to inhibit wide range of spoilage fungi. Such bacteria can be applied to enhance shelf-life of vegetables.

From this review concluded that the abundant growth of bacteria can be seen on nutrient agar or MRS is known to be the selective media for lactic acid bacteria and most recommended for isolation of lactic acid bacteria. It was concluded that it can found in both shapes that is rod and cocci can also live-in absence of oxygen as it is facultative anaerobe.In this study reported that lactic acid bacteria are very important.

\section{ACKNOWLEDGMENT}

It's our privilege and honour to express our sincerest gratitude to the Parul University, Vadodara, Gujarat for providing me all the necessary support and facilities including state of the art infrastructural facilities with advanced technological scientific laboratories and everything else that was required to carry out this work.

\section{REFERENCE}

[1] Chen Y. S., Yanagida F: Isolation and identification of lactic acid 
bacteria from soil using an enrichment procedure. Letters in applied microbiology. Oct 2004; 40(3): 195-200.

[2] Emmanuel E., Andrew A: Isolation, identification and characterization of some bacteria from soil samples of agbaja iron ore mining site of kogi state. J Bacterial Mycol Open Access. March 2017; 4(3): 79-84.

[3] Gowsalya A., Ponnusami V: Isolation of bacteria from soil sample for exo-polysaccharide production. International Journal of ChemTech Research. Aug- Sep 2014; 6(5): 2925-2928.

[4] LutzM. P., Michel V et al: Lactic acid bacteria as biocontrol agents of soil-borne pathogens. Biological Control of Fungal and Bacterial Plant Pathogens. Jan 2012; 7(8): 285-288.

[5] ChenY. S, Hui-Chung wu et al: Isolation and characteristics of lactic acid bacteria isolated from ripe mulberries in Taiwan. Brazilian Journal of Microbiology. April 2010; 41(4): 916-921.

[6] YuliarY., Abidin Z et al: Potency of biocontrol agents isolated from compost and peat soil of tropical peat swamp forest in Kalampangan zonecentral Kalimantan. Indonesian Journal of Forestry Research.2011; 8(2): 144-157.

[7] Naeem M., Ilyas $M$ et al: Isolation characterization and identification of lactic acid bacteria from fruit juices and their efficacy against antibiotics. Pak J Bot. March 2012; 44(323): 810.

[8] Akcelik O., Tükel C et al: "Characterization of bacteriocins from two Lactococcus lactis subsp. lactis isolates." Molecular nutrition \& food research March 2006; 50(3): 306-313.

[9] Chambel Lelia, Ivo M. Chelo et al: Leuconostoc pseudoficulneum sp. nov., isolated from a ripe fig." International journal of systematic and evolutionary microbiology. June 2006; 56 (6): 1375-1381.

[10] Endo A., Futagawa-Endo, Y: Isolation and characterization of fructophilic lactic acid bacteria from fructose-rich niches. Systematic and Applied Microbiology. Dec 2009; 32(8): 593-600.

[11]Chen, Y.S., Yanagida, F et $a l:$ "Isolation and identification of lactic acid bacteria from soil using an enrichment procedure." Letters in 
applied microbiology. May 2005; 40(3): 195-200.

[12] Litchfield, J. H: Microbiological production of lactic acid. Advances in applied microbiology.1996; 42: 45-95.

[13] Wilfrid S P, Schillinger U et al: Weissella beninensis sp. nov., a motile lactic acid bacterium from submerged cassava fermentations, and emended description of the genus Weissella. International journal of systematic and evolutionary microbiology. Sept 2002; 60(9): 2193-2198.

[14] Björkroth K J, Schillinger U et al: Taxonomic study of Weissella confuse., and description of Weissella cibaria: detected in food and clinical samples. International Journal of Systematic and Evolutionary Microbiology. Jan 2002; 52(1): 141-148.

[15] Axelsson, L. Marcel dekker: Lactic acid bacteria classification and physiology. Food science and technology-newYork.2004; 139: 166.

[16] DeVuyst, Land Bart D: "Heteropolysaccharides from lactic acid bacteria." FEMS microbiology reviews. April 1999; 23 (2): 153177. 